\title{
Development of Mini Tractor Operated Combination Tillage Implement
}

\author{
M. Inthiyaz ${ }^{*}$, C. Tejaswini, P. Sivakumar and D. Srigiri \\ College of Agricultural Engineering, Madakasira, ANGRAU, \\ Andhra Pradesh - 515301, India \\ *Corresponding author
}

\section{A B S T R A C T}

\begin{tabular}{l} 
K e y w o r d s \\
$\begin{array}{l}\text { Combination tillage } \\
\text { implement (IP-DH), } \\
\text { Disc harrow (DH), } \\
\text { Iron plough (IP) }\end{array}$ \\
\hline Article Info \\
$\begin{array}{l}\text { Accepted: } \\
15 \text { August } 2020 \\
\text { Available Online: } \\
10 \text { September } 2020\end{array}$ \\
\hline
\end{tabular}

A combination tillage implement operated with mini tractor was developed. The implement was evaluated for width of operation, depth of cut, operating speed, wheel slip, field capacity, field efficiency and fuel consumption, quantity and quality of work done by the implement which includes soil inversion, soil pulverization and volume of soil handled per unit area and also the economics of operation were calculated. The developed IP-DH implement can be operated up to depth of $16.88 \mathrm{~cm}$ and width of $1.056 \mathrm{~m}$ at an operating speed of $2.16 \mathrm{~km} / \mathrm{h}$. The theoretical field capacity and actual field capacity of IP-DH implement were found to be $0.228 \mathrm{ha} / \mathrm{h}$ and $0.161 \mathrm{ha} / \mathrm{h}$ which gives an efficiency of $70.6 \%$. The tillage time that can be saved up to $53.62 \%$. The fuel consumption was found to be 1.75.1/h for IP-DH implement and fuel can be saved up to $53 \%$. The Mean Mass Diameter (MMD) of soil clods after the passage of IP-DH implement was found to be $10.26 \mathrm{~mm}$ and the soil inversion was found to be $93.9 \%$. The volume of soil handled per unit area was $271.76 \mathrm{~m}^{3} / \mathrm{h}$. The cost of operation was Rs.322/h and save of $53 \%$ as compared to conventional tillage implement.

\section{Introduction}

Indian agriculture account for nearly $14.2 \%$ of the gross domestic product and involves over $58.2 \%$ of population (Anon., 2011a). The biggest challenge before the agricultural sector of India is to meet the growing demands of food for its increasing population from 1.21 billion in the year 2011 to 1.6 billion by the year 2050 (Anon., 2011a). Since the cultivated area has remained nearly constant (142 Mha; Anon., 2011b) over the years, the only option to increase food production is to increase the productivity of land. This can be achieved by increasing cropping intensity and reducing turnaround time through increased mechanization. However, the mechanization level in India is quite low. The application of machines to agricultural production has been one of the outstanding developments in Indian agriculture. The efficient utilization of available resources and timeliness of agricultural operation are the major factors influencing the productivity level of agricultural commodities. Conventional tillage employs many passes over a field with various soil-turning and soil-pulverizing 
equipments: mould board plough, disk harrow, spike-toothed harrows and cultivators etc. Such conventional tillage operations require expensive machinery and high fuel consumption and contribute to compaction of the soil (Claassen, 1996). Also in conventional tillage practices most of the Indian farmer utilizes the available tillage implement with any ranges of tractor power, consequently there is improper matching of tractor and implement combinations resulting in under loading of tractor engine hence, poor efficiency (Alam, 2000). These difficulties can be overcome by either increasing speed of operation and width of cut of tillage implements or reducing the number of passes required for tillage operations to prepare the seedbed without sacrificing the quality of work. As the land sizes in India are small, the scope for increasing the speed or width of existing implements is less feasible. Hence, reducing the number of passes by combining two or more field operations with the use of combination tillage implements may provide better solution (Sahu and Raheman, 2006). The combination tillage implements also help in reducing time, labor and fuel costs for seedbed preparation (Downs, 2003). The combination tillage implement comprises either active-passive or passive-passive tillage elements. Some studies on development and performance evaluation of $2 \mathrm{WD}$ tractor drawn combination tillage implements have been conducted in India (Kumar and Manian, 1986; Manian et al., 1999; Kailappan et al., 2001a and b., Sahu, 2006).

\section{Materials and Methods}

For selecting combination tillage implement, the draft and power requirements of the different primary and secondary implements were selected. The total power requirement of combination implement was calculated. The combination of iron plough as primary tillage implement and disc harrow as secondary tillage implement having the same width of operation and the power requirement of the combination tillage implement was feasible as per the power availability of mini tractor.

\section{Design of component}

For combination tillage implement, the primary tillage implement as iron plough was selected and designed for the purpose of primary tillage operation.

\section{Iron plough (Fig. 1)}

\section{Frame assembly}

The frame assembly was designed considering the following requirements:

The frame should be able to support the main sub assembly of disk harrow.

It should be adequate to withstand bending, torsion and shear forces to be experienced during tillage operation.

It should be a simple welded structure having a section modulus with maximum strength and minimum weight.

\section{Plough bottoms}

The following design requirements were considered for plough bottom.

The overall cutting width of the iron plough was kept as $0.9 \mathrm{~m}$ with equal spacing of 30 $\mathrm{cm}$. It should be able to open the soil up to a depth of $20 \mathrm{~cm}$.

An adjustable shovel is provided on the plough bottom and it can be adjusted by bolt and nut with an equal spacing of $7.5 \mathrm{~cm}$.

Iron plough is a multipurpose tool and it can also be used for making furrows also. 


\section{Disc harrow (Fig. 2)}

The following design requirements were considered for disc harrow.

The overall cutting width of the harrow was kept as $0.9 \mathrm{~m}$ with a gap of $0.17 \mathrm{~m}$ at the center to cover the soil opened by iron plough.

A diameter of $47 \mathrm{~cm}$ discs were used because small diameter discs penetrate more readily than large discs, i.e., they require less vertical force to hold them to given depth.

The harrow should be kept behind the iron plough with certain gap to avoid clogging.

Adequate overlap was provided to minimize the untilled soil.

\section{Test procedure}

All the field experiments were conducted on Research Farm of College of Agricultural Engineering, Madakasirain a field size of $25 \mathrm{mx} 10 \mathrm{~m}$. The following parameters are to be measured for the field evaluation of developed combination implement.

\section{Measurement of soil properties}

In order to quantify the soil condition moisture content and bulk density were obtained in each plot at a depth of $15 \mathrm{~cm}$.

\section{Moisture content}

The draft is dependent on soil moisture to great extent. Soil sample were taken up to maximum ploughing depth of tillage. The soil moisture analysis was done by oven drying method. Moisture content was found out on dry weight basis.

Soil samples were collected at different places. The weight of wet soil sample was measured and then soil sample was put in an oven at $105^{\circ} \mathrm{C}$ for 24 hours and then the weight of dry sample was measured. The following formula was used for calculating the soil moisture content (Javadi and Hajiahamad, 2006).

Moisture content of soil $(\%$ d.b $)=$

Weight of wet soil(g)-Weight of dry soil (g) Weight of dry soil (g)

\section{Bulk density}

For measurement of bulk density of soil cylindrical core samples of soil were taken from at least three locations selected randomly in the test measurement. The diameter and length of cylindrical soil samples were measured.

Bulk density $\left(\mathrm{kg} / \mathrm{m}^{3}\right)=\frac{\text { Mass }}{\text { Volume }}$

Measurement of tillage performance parameters

The tillage performance parameters such as soil inversion, width of cut, depth of cut, field capacity, field efficiency and fuel consumption were measured (Fig. 3).

\section{Width of operation}

For determining width of cut, average of 5 runs had taken. The measurement of composite width was taken at 5 equidistant places in the direction of travel and average working width was determined.

\section{Depth of operation}

The vertical distance between furrow sole and ground level is referred as depth of cut. To obtain accurate result, the depth was measured at 10 places and its average was taken. 


\section{Measurement of operating speed}

For determination of speed of operation, the time was noted with the help of stopwatch to cover the distance of $25 \mathrm{~m}$ travelled by the tractor. It directly gives speed of operation by following formula

Speed $(m / s)=\frac{\text { Distance }}{\text { Time }}$

\section{Measurement of wheel slip of tractor}

The measurement of wheel slip was based on the fixed number of rear wheel revolution. The distance covered in ten-wheel revolutions was recorded with and without load and the values were used to calculate slip using the following expression.

$$
\mathrm{S}(\%)=\frac{\mathrm{d}_{\mathrm{t}}-\mathrm{d}_{\mathrm{a}}}{\mathrm{d}_{\mathrm{t}}} \times 100
$$

Where

$\mathrm{S}=$ wheel slip $(\%)$

$\mathrm{d}_{\mathrm{t}}=$ distance covered in 10 revolutions of drive wheel at no load in field

$d_{a}=$ distance covered in 10 revolutions of drive wheel with load in field

\section{Field capacity}

The effective field capacity of machine can be expressed as the actual rate at which, it can do work, taking into account non-productive operations such as turning at the ends of the field, stopping to add seed or fertilizer and stopping to check the performance of a particular equipment (Fig. 6).

The actual field capacity (AFC) was determined by the following formula:

$\operatorname{AFC}(h a / h)=\frac{\text { Area covered }}{\text { Time taken }}$
The Theoretical field capacity (TFC) was determined by the following formula:

$\mathrm{TFC}(h a / h)=\frac{\text { width of coverage Xspeed of travel }}{10}$

\section{Field efficiency}

The field efficiency is the ratio of effective field capacity to the theoretical field capacity expressed as percentage.

Field efficiency $(\mathrm{I})=\frac{\mathrm{AFC}}{\mathrm{TPC}} \times 100$

\section{Fuel consumption}

The fuel consumption is measured by volume displacement method. The tank was filled to full capacity before and after the test. Amount of refueling after the test was the fuel consumed for the test. The tank was filled without any empty space. The fuel consumption gives an idea of energy requirement by the implement for the operation (Fig. 5).

Quantity and quality of work done by the implement

\section{Soil inversion}

Soil inversion was taken as ratio of number of weeds or stubbles of last crop left on soil surface after operation to that before it. A square frame having sides $100 \mathrm{~cm}$ was used for counting weed or the stubbles.

$\mathrm{F}(\%)=\frac{\mathrm{B}-\mathrm{A}}{\mathrm{B}} \times 100$

Where,

$\mathrm{F}=$ indicator for soil inversion

$\mathrm{B}=$ no. of weeds or crop stubble before operation per unit area

$A=$ no. of weeds or crop stubble exposed on the surface after operation. 


\section{Measurement of soil pulverization}

Soil pulverization is the process of breaking of soil into small aggregates resulting from the action of tillage forces. The mean mass diameter (MMD) of the soil aggregates is considered as index of soil pulverization and can be determined by the sieve analysis of the soil sample through a set of standard test sieves (IS: 460-1982). Sieve provides a simple means for measuring the range of clod size and relative amount of soil in each size class (Fig. 4).

\section{Volume of soil handled}

The volume of soil handled was calculated by multiplying the field capacity with the depth of cut (Ahaneku et al., 2011).

$\mathrm{V}\left(\mathrm{m}^{3} / \mathrm{h}\right)=10000 \mathrm{SD}$

Where,

$\mathrm{V}=$ Volume of soil handled $\left(\mathrm{m}^{3} / \mathrm{h}\right)$

$\mathrm{S}=$ Effective field capacity $(\mathrm{h} / \mathrm{h})$

$\mathrm{D}=$ Depth of cut $(\mathrm{m})$

\section{Cost analysis}

In order to evaluate the cost effectiveness of tillage operation, the cost incurred for the combination tillage operation (Rs/ha as well as $\mathrm{Rs} / \mathrm{h}$ ) was computed and added (Sahay, 2008). The cost analysis is divided into two heads known as fixed cost and operating cost (variable cost). Depreciation was calculated using straight line method.

\section{Results and Discussion}

\section{Development of combination tillage}

\section{Implement}

Based on the output of simulation study, a combination tillage implement comprising of
Iron plough and Disc harrow (IP-DH) was developed. The overall dimensions are $1.27^{\times} 0.9^{\times} \times 0.8 \mathrm{~m}$ and the weight of implement was $185 \mathrm{~kg}$.

Performance study of primary, secondary and combination tillage implement

The results of the field experiments are presented in this chapter along with its discussion. The data pertaining to soil moisture content, bulk density, operating speed, travel reduction, draft, fuel consumption, field capacity, energy requirement, soil pulverization and drawbar power were analyzed. Results are presented under the following manner:

Measurement of soil properties

Measurement of tillage performance parameters

Quantity and quality of work done by the implement

\section{Measurement of soil properties}

\section{Moisture content}

The mean data on soil moisture content before tillage operations at $0-15 \mathrm{~cm}$ depth collected with the help of soil sampler. The moisture content of the soil which provides satisfactory tillage operation should be in the range of 13$16 \%$ on dry basis. The moisture content obtained in the research plot was $14.53 \%$.

\section{Bulk density}

The mean data on bulk density before and after tillage operations at $0-15 \mathrm{~cm}$ depth were recorded. The results show that the average bulk density recorded at $0-15 \mathrm{~cm}$ depth was $1.7 \mathrm{~g} / \mathrm{cc}$ before tillage operation. After using iron plough for initial opening up of soil bulk density had reduced in a considerable which was $1.4 \mathrm{~g} / \mathrm{cc}$ approximately. Again, secondary 
tillage operation was continued for reducing clod size as well as increasing porosity, therefore the bulk density obtained was 1.31 $\mathrm{g} / \mathrm{cc}$. The bulk density obtained after combination tillage operation with iron plough and disc harrow was $1.27 \mathrm{~g} / \mathrm{cc}$.

\section{Measurement tillage performance parameters}

\section{Width of operation}

The width of cut of tillage implement was measured by measuring the width of furrow with a measuring tape at an interval of about 5 $\mathrm{m}$ along the length of furrow. The average of ten readings was taken to determine the width of cut of an iron plough, disc harrow and IP$\mathrm{DH}$, the average width of operation was found to be $1.055 \mathrm{~m}, 0.948$ and 1.056 respectively.

\section{Depth of operation}

The average depth of operation of an iron plough, disc harrow and combination tillage implement were $16.01 \mathrm{~cm}, 12.82 \mathrm{~cm}$ and $16.88 \mathrm{~cm}$ respectively. The depth of cut of tillage implement effects the total volume of soil handled per unit area and the draft requirement. The depth of cut was found to be more for combination tillage implement due to more weight of the implement compared to the individual implements. It does not have much effect on field capacity.

\section{Field capacity and field efficiency}

The field capacity of an iron plough is a function of its width, speed, efficiency of operation and soil parameter. The size of the testing plot was kept $25 \mathrm{~m} \times 10 \mathrm{~m}\left(250 \mathrm{~m}^{2}\right)$ (Fig. 7).

Fig.1 Iron plough

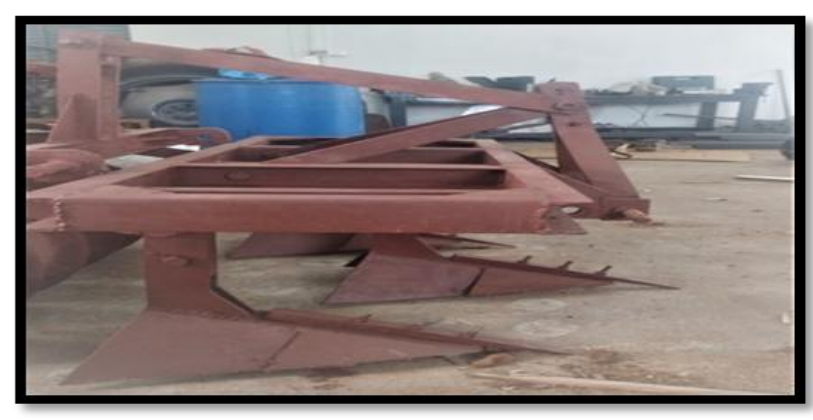

Fig.2 Disc Harrow

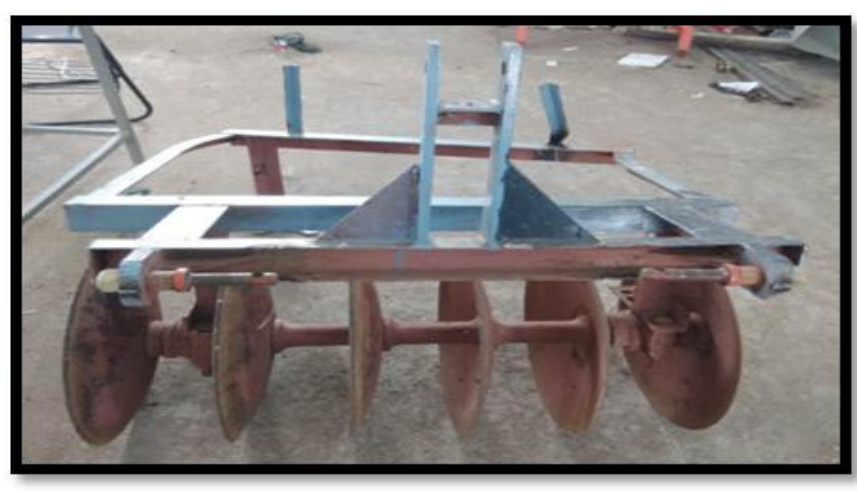


Fig.3 Combination tillage implement

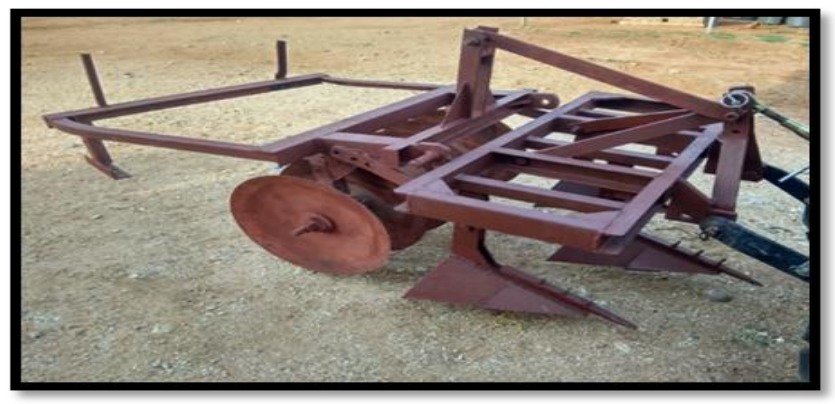

Fig.4 Comparison of mass mean diameter

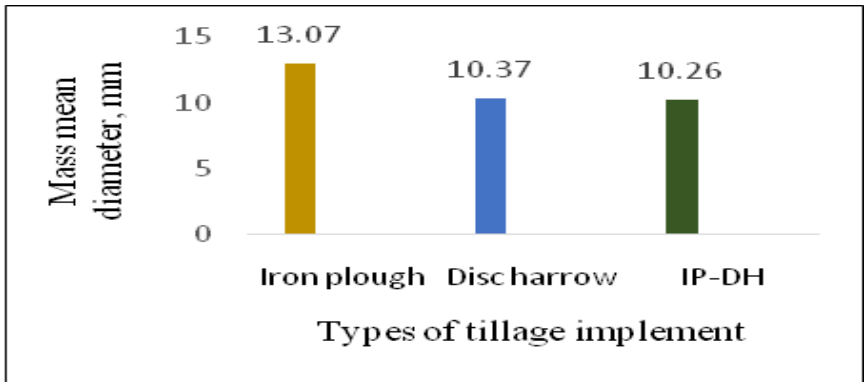

Fig.5 Comparison of fuel consumption

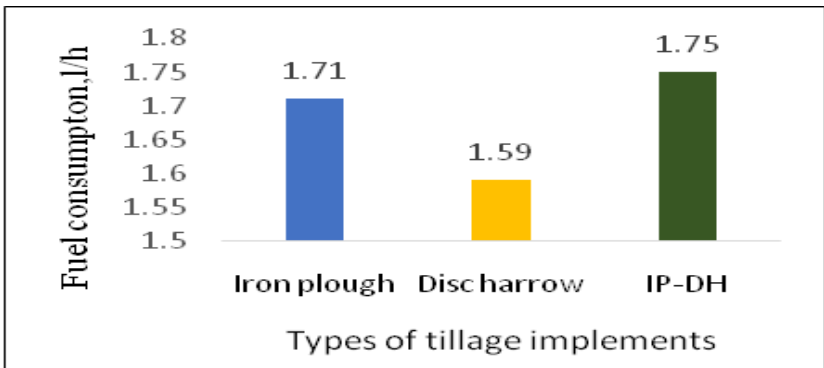

Fig.6 Comparison of field capacity

\begin{tabular}{|c|c|c|c|c|c|}
\hline \multirow{6}{*}{ 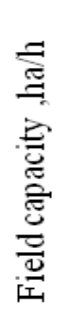 } & 0.25 & 0.221 & 0.235 & 0.228 & \\
\hline & 0.2 & 0.164 & 0.182 & 0.161 & \multirow{5}{*}{$\begin{array}{l}=\text { TFC } \\
=\mathrm{AFC}\end{array}$} \\
\hline & 0.15 & & & & \\
\hline & 0.1 & & & & \\
\hline & $\begin{array}{r}0.05 \\
0\end{array}$ & & & & \\
\hline & & IP & $\mathrm{DH}$ & IP-DH & \\
\hline & & Typeso & age & plements & \\
\hline
\end{tabular}


Fig.7 Comparison of cost of operation

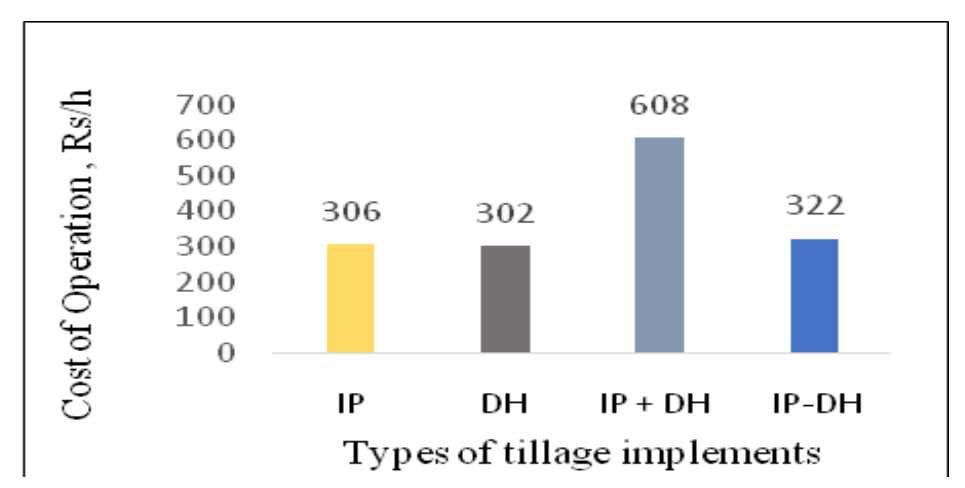

For primary tillage implement (Iron plough)

The width of operation for iron plough was $1.055 \mathrm{~m}$. The theoretical field capacity and actual field capacity of the iron plough was $0.221 \mathrm{ha} / \mathrm{h}$ and $0.164 \mathrm{ha} / \mathrm{h}$ respectively. The field efficiency was found to be $74.12 \%$.

\section{Secondary tillage implements (Disc harrow)}

The width of operation for disc harrow was $0.948 \mathrm{~m}$. The theoretical field capacity and actual field capacity of the disc harrow was $0.235 \mathrm{ha} / \mathrm{h}$ and $0.182 \mathrm{ha} / \mathrm{h}$ respectively. The field efficiency was found to be $77 \%$.

Combination tillage implement (Iron plough \&Disc harrow)

The width of operation for IP-DH was $1.056 \mathrm{~m}$. The theoretical field capacity and actual field capacity of combination tillage implement was $0.228 \mathrm{ha} / \mathrm{h}$ and $0.161 \mathrm{ha} / \mathrm{h}$ respectively. The field efficiency was found to be $70.6 \%$.

\section{Fuel consumption}

The fuel consumption gives an idea of energy requirement by the implement for the tillage operation. In order to determine the energy requirements as well as cost of operation for iron plough, disc harrow and combination tillage implement were calculated. The fuel consumption obtained for Iron plough, Disc harrow and Iron plough \& Disc harrow were $1.71 \mathrm{l} / \mathrm{h}, 1.59 \mathrm{l} / \mathrm{h}$ and $1.75 \mathrm{l} / \mathrm{h}$ respectively.

\section{Wheel slip}

Wheel slip was calculated by determining the speed of operation with load and without load. The wheel slip obtained for primary, secondary tillage implement and combination tillage implement were $13.2 \%, 2.78 \%$ and $15.6 \%$ respective

\section{Speed of operation}

For determination of speed of operation, the time was recorded with the help of stopwatch to cover the distance of $25 \mathrm{~m}$ travelled by the tractor. The average speed of operation obtained for primary, secondary and combination tillage implements were 2.1 $\mathrm{km} / \mathrm{h}, 2.42 \mathrm{~km} / \mathrm{h}$ and $2.166 \mathrm{~km} / \mathrm{h}$ respectively.

Quantity and quality of work done by the implement

\section{Soil pulverization}

The clod mean-mass-diameter is an index for indirect measurement of tilth of soil. It has 
been indicated that soil aggregates of size less than $15 \mathrm{~mm}$ in the final seedbed are adequate for sowing crops. After the primary tillage operation, the mean mass diameter (MMD) obtained with the iron plough was $13.07 \mathrm{~mm}$. There was considerable improvement in soil pulverization with the use of the disc harrow due to the ability to break the clod formed in the primary tillage operation. The mean mass diameter obtained in secondary tillage operation was $10.37 \mathrm{~mm}$. The mean mass diameter obtained with combination tillage operation (Iron plough \& Disc harrow) was $10.26 \mathrm{~mm}$.

\section{Soil inversion}

The soil inversion was determined by calculating the number of weeds collected from an area of $100^{\times} 100 \mathrm{~cm}$ before and after tillage operation carried out by the tillage implements. The number of weeds obtained before operation was 80 and after primary and secondary tillage operations were 20 and 5 . Soil inversion obtained for primary and secondary tillage operations were $75 \%$ and $93.75 \%$ respectively. While using combination tillage implement the number weeds in the field before tillage operation was 115 and after the operation was only 7 weeds were left. Hence the soil inversion was found to be $93.9 \%$ for combination tillage operation.

\section{Volume of soil handled per unit time}

The volume of soil handled per unit time during primary, secondary and combination tillage operations were calculated knowing the implement width, speed and depth of operation for each tillage implement tested and was found to be varying from $262.5 \mathrm{~m}^{3} / \mathrm{h}$ to $233.3 \mathrm{~m}^{3} / \mathrm{h}$. The volume of soil handled by combination tillage was $271.76 \mathrm{~m}^{3} / \mathrm{h}$. It was observed that, with increase in either speed of operation or depth, volume of soil handled increased.

\section{Cost estimation}

The cost of operation for Iron plough, Disc harrow and Combination of IP-DH were 306 Rs. /h, 302 Rs. /h and 322 Rs. /h respectively.

Comparison of developed combination tillage implement with conventional tillage implement

The cost of developed combination tillage implement (IP-DH) was estimated to be Rs.22500. It was suitable and economical for completion of tillage operation in a single pass as compared to the conventional tillage implement. The developed IP-DH implement can be operated up to depth of $16.88 \mathrm{~cm}$ and width of $1.056 \mathrm{~m}$ at an operating speed of 2.16 $\mathrm{km} / \mathrm{h}$. The theoretical field capacity and actual field capacity of IP-DH implement was found to be $0.228 \mathrm{ha} / \mathrm{h}$ and $0.161 \mathrm{ha} / \mathrm{h}$ which gives an efficiency of $70.6 \%$.The tillage time that can be saved up to $53.62 \%$.The fuel consumption was found to be $1.75 .1 / \mathrm{h}$ for IPDH implement and fuel can be saved up to 53\%.The Mean Mass Diameter (MMD) of soil clods after the passage of IP-DH implement was found to be $10.26 \mathrm{~mm}$ and the soil inversion was found to be $93.9 \%$.The volume of soil handled per unit area was $271.76 \mathrm{~m}^{3} / \mathrm{h}$. The cost of operation was Rs.322 /h and save of $53 \%$ as compared to conventional tillage implement. Based on the performance results, it was concluded that the combination tillage implement operated with mini tractor can be efficiently, effectively and economically used by majority of the farmers for their cultivation.

\section{References}

Buschiazzo, D. E.; Panigatti, J. L. and Unger, P. W. (1998). "Tillage effects on soil properties and crop production in the subhumid and semiarid Argentinean 
Pampas". Soil \& Tillage Research, 49:105-116.

Chandegara, V. K. (2003). "Design and developing of bullock drawn multipurpose implement for sandy loam soil". Journal of Agricultural Engineering, 40(4):22-26.

Dhankane, A.D., Turbatmath, P.A., and Pandey,.V (2010). "The field performance evaluation of tractor operated combination tillage implement". International journal of Agricultural Engineering. 3(1):138143.

Hajiahmad A and Javadi A, (2006). "Effect of a New Combined Implement for Reducing Secondary Tillage Operation". International Journal of Agriculture \& Biology, vol. 8:724-727. Kailappan R, Swaminathan HR, Vijayaraghavan NC and Amuthan G, (2001b). "Combination tillage tool - II (Performance evaluation of the combination tillage tool under field conditions)". Agricultural mechanization in Asia, Africa and Latin America, 32(4): 9-12.

Kttikhunprasertkan and Prathuangusaborisut (2018). "Performance test of combination tillage tool". Proceedings of $99^{\text {th }}$ The IRES International Conference, Hanoi, Vietnam.

Kumar VJF and Manian R, (1986). "Tractordrawn combination tillage tool". Agricultural mechanization in Asia, Africa and Latin America, 17(1): 3136.
Loghavi M and A Hosseinpoor, (2002). "Investigating the effect of attaching roller to mouldboard plough on primary and secondary tillage operation". Proceeding of Second National Congress on Farm Machinery and Mechanization, Karaj, Iran.

Manian R, Nagaiyan V and Kathirvel K, (1999). "Development and evaluation of combination tillage bed furrowformer". Agricultural mechanization in Asia, Africa and Latin America, 30 (4): $22-29$.

Manjeeth Prem, Swarnkar, R, Vyas, D.K, Pargi, S.J and Khodifad, B.C, (2016). "Combination Tillage Tools". Current Agriculture Research Journal, 4(2): 179-185.

Manjeeth Prem, Prem Ranjan, Dabhi.K.L, Baria, A.V, and Pema T. Lepcha (2017). "Use of different tillage tools for minimizing number of passes in secondary tillage operations". International Journal of Current Microbiology and Applied Sciences, 6(12): 3109-3116.

Upadhyaya SK, Lancas KP, Santos-Filho AG and Raghuwanshi NS, (2001). "Onepass tillage equipment outstrips conventional tillage method. California agriculture", 55(5): 44-47.

Weise G, (1993). "Active and passive elements of a combined tillage machine: Interaction, draught requirement and energy consumption". Journal of Agricultural Engineering Research, 56(4): 287-299.

\section{How to cite this article:}

Inthiyaz, M., C. Tejaswini, P. Sivakumar and Srigiri, D. 2020. Development of Mini Tractor Operated Combination Tillage Implement. Int.J.Curr.Microbiol.App.Sci. 9(09): 1894-1903. doi: https://doi.org/10.20546/ijcmas.2020.909.239 